\title{
Interediting: Revealing the Dual Role of Staff Interpreters on Turkish News Channels
}

\author{
Özüm ARZIK ERZURUMLU*
}

Full-time interpreters serving on TV outlets in Turkey hold two roles: they serve both as editors for the world news desk and as simultaneous interpreters. Drawing on interviews made with editor/interpreters and editors-in-chief and corroborating these with real-life interpreting instances, this paper investigates the relationship between editing and interpreting. It is found that the editing task assumed by interpreters/journalists bears upon the lexical choices made in interpreting on television news channels in Turkey. It is therefore claimed that familiarization with the language of the news helps staff interpreters in making renditions that follow the institutional policies of the outlets they serve, thus informing the interpreting output. Drawing on the term transediting, coined by Karen Stetting (1989) to describe the role of journalists, it is asserted that the role of these editor/interpreters might be described as that of 'intereditors.' It is the contention of the paper that interediting might prove useful in describing the TV interpreting of staff interpreters in Turkey.

Keywords: TV interpreting; transediting; interediting; news translation; interpreting

\section{Introduction}

The present paper, drawn from my doctoral research, attempts to examine the dual role of in-house interpreters working for news channels (hereinafter referred to as NC) in Turkey. The paper investigates how the editing role assumed by staff interpreters manifests itself in the process of interpreting. By drawing on the self-narratives of the interpreters and editors-inchief serving on the four news channels selected for the purposes of the paper, analyzing them in concert with the interpreting assignments carried out for these channels, and corroborating them with the interpreting cases acquired from these channels, the paper is an attempt to shed light on the inextricable relationship between interpreting and editing. The goal is to investigate how editing and serving as a journalist impinge on interpreting output and how interediting, denoting interpreting and editing happening simultaneously in rendering, becomes operational in the process.

\footnotetext{
* Part-Time Instructor at Istanbul 29 May1s University. E-mail: ozumarzik@gmail.com; ORCID ID: https://orcid.org/0000-0002-6515-0558. (Received 25 January 2019; accepted 14 June 2019)
} 
transLogos 2019 Vol 2 Issue 1

Arzık Erzurumlu, Özüm, pp. 68-84

The paper first looks into TV interpreting, examining interpreting for news channels in Turkey in detail. Following the review of the TV interpreting literature, I hypothesize that the term interediting might be employed to explicate the role of the interpreters/journalists and the process of interpreting perpetuated in the news channels in Turkey. Then I describe the methodology, followed by the interview findings, and an analysis of the interpreting occurrences. The article concludes with a discussion of why interediting might be gauged to describe the interpreting of staff interpreters in Turkey.

\section{TV Interpreting: The Turkish Case}

Interpreting perpetuated on TV - separate from media or broadcast interpreting - has become established as a different form of interpreting in recent years (Pöchhacker 2011a). To Dal Fovo $(2015,245)$, the term TV interpreting is "the least inclusive" of all, since the other names - media or broadcast - might cover interpreting on radio or even live streaming, which is very frequently seen in big events. I choose to use TV interpreting, since the research has been conducted on TV channels, and not radio or other electronic media outlets.

The literature describes TV interpreting as a stressful profession (Kurz 2002). Comparing the stress level of TV interpreters and conference interpreters, Kurz found that TV interpreters work under greater stress than conference interpreters. She revealed that lack of time for preparation, information density, and the speed of delivery are among the elements of stress (Kurz 1993). Adding onto those stress factors is the importance of the speech/speakers and the speech's being full of cultural references (Pöchhacker 2007; Munday 2017; Arzik Erzurumlu, 2019). Moreover, another major difficulty in TV interpreting lies in the fact that the delivery of the TV interpreter is mostly checked against the presenters by the audience. Since the TV audience is accustomed to hearing people speak with good diction on TV, their expectation of the interpreter's performance is the same. To meet this expectation, Viaggio (2001) claims that TV interpreters need to be seasoned communicators and consummate mediators.

The literature emphasizes the following difficulties in working as a TV interpreter: synchronization (Kurz 1990; Snelling 1997), following the news at all time (Buck and Tsuruta 2012), tackling any subject, speaker, or dialect at any time in an unexpected manner, seldom having time to prepare for an assignment, interpretation's being part of mass consumption 
transLogos 2019 Vol 2 Issue 1

Arzık Erzurumlu, Özüm, pp. 68-84

trans Dogos

A Translation Studies Journal

Interediting: Revealing the Dual Role of Staff

Interpreters on Turkish News Channels

(C) Diye Global Communications diye.com.tr|diye@diye.com.tr

(Viaggio 2006), the assignments' being at unusual hours and being given on short notice, nonstandard working conditions (Pöchhacker 2007), and having to explicate cultural specific concepts under time pressure (Kurz 1993). Pöchhacker (2007, 140), summarizing the difficulties in one single term, maintains that TV interpreters are like "rope dancers" in that they need to tackle a high level of exposure in interpreting a highly important speech from a different culture. To him, given this difficulty, the interpreters might resort to substitution or omission in the face of culturally loaded or difficult terms. In the literature, the fact that TV interpreting requires different norms such as omission has also been discussed. Tsuruta (2011, 160) maintains that in TV interpreting perpetuated in Japan, brand names must be omitted. If the speaker says "Coke," the interpreter should render it as "fizzy drink." Offering a different perspective, Dal Fovo $(2013,416)$ added that there are also some internal habits such as "conscious deliberate choices" and "decisional patterns" on top of the external constraints.

The literature on TV interpreting is instructive on the profession in Turkey. In the Turkish case, it was the First Gulf War in the 1990s which introduced TV interpreting and interpreters to large masses. ${ }^{1}$ Back then, the interpreters interpreting for the one and only private TV channel in Turkey had to fly to Germany and interpret in the studio based in Germany, working on shifts. ${ }^{2}$ Since then, significant progress has been made in the sense that major TV channels, especially news channels, employ full-time interpreter(s). The importance placed on interpreting increased alongside the improvements in broadcasting since the number of private channels in the country multiplied throughout the 1990s. The news channels have served as an internship opportunity especially for the new graduates of translation and interpreting departments. Since it might be difficult for new graduates to go directly into the conference interpreting industry due to the presence of a wide range of gatekeepers in place (Pöchhacker 2011b), TV interpreting could offer an easier entry into the profession. This dynamic seems to have helped to make TV interpreting in Turkey a professionally established domain.

As regards the interpreting mode in these news channels, the most preferred form is simultaneous mode, with the consecutive mode employed in talk shows and interviews. In the interpretation of internationally covered events such as political speeches, international award

\footnotetext{
1 “Savaşla hatırlananlar," Milliyet, September 30, 2001, accessed March 10, 2019, http://www.milliyet.com.tr/2001/10/06/pazar/paz03.html.

2 "Savaşın sesini duyurdular," accessed March 10, 2019, http://www.ukt.com.tr/images/basinda/normal/ukt24.jpg.
} 
transLogos 2019 Vol 2 Issue 1

Arzık Erzurumlu, Özüm, pp. 68-84

ceremonies, or major sports events, interpreting in absentia (Falbo 2012; Pöchhacker 2010), denoting the interpreter's not sharing the same physical location as the speaker(s), is employed. In the Turkish case, the interpreters and the speakers often do not even share the same time zone, the most outstanding example of which might be interpreting the American presidential debates or the Oscars awards ceremony, which are broadcast at three o'clock A.M. Turkish time. ${ }^{3}$

Since the 2000s, that is, for almost two decades, major news channels have been hiring in-house interpreters. Two major examples are CNNTürk and Habertürk. CNNTürk has employed full time in-house interpreter(s) who have also served as editors on the world-news desk ever since the First Gulf War broke out. Habertürk has employed full time interpreters and editors for the last thirteen years. As might be seen in these examples, not only do these TV interpreters interpret live but they also serve as editors. One of the former heads of Habertürk maintains that hiring one person who has two titles is a budget related decision that is made because it is more cost-effective (anonymous respondent, pers. comm.). Moreover, holding an editor as well as interpreter title helps interpreters in their rendition of political issues. Since interpreters take an active role in selecting and writing political news as editors when they are not in their interpreter role, managers believe this improves the interpreters' grasp over the past/present and future of a subject and leads to subtlety and nuance in rendering.

Dal Fovo (2015 247) contends that since it is easy to access broadcasting content, media interpreting "lends itself to empirical research." This research, an empirical study, will not only analyze the broadcasting content but also draw on the interviews conducted with TV interpreters, attempting to unearth the contours of the dual role and reveal the interaction between these roles. Since the interpreters/journalists hold dual roles in the news channels, in what follows interediting will be presented as a term to explicate their role.

\section{Interediting}

Kurz $(1997,197)$ maintains that TV interpreting is a form of communicative language transfer necessitating editorial decisions, content related judgments, and cultural considerations. The editorial decisions made by the interpreter, however, remain understudied

\footnotetext{
${ }^{3}$ For a paper that discusses the way that American presidential debates are interpreted for the news channels in Turkey, see Arzık Erzurumlu (2019).
} 
transLogos 2019 Vol 2 Issue 1

Arzık Erzurumlu, Özüm, pp. 68-84

in the literature, whereas the editorial roles assumed by the translators and their implications regarding the output have been widely discussed in the literature on translation (e.g. Hursti 2000; Schäffner 2008). In one of these studies, Karen Stetting (1989) coined the term "transediting," a blend of translation and editing, to illustrate the role of journalists. For her, the transeditor adopts an interventionist approach rather than a conduit one. She, therefore, puts transediting into three groups (377): cleaning up transediting (offering efficiency in expression), situation transediting (abiding by the intended function of the translation), and cultural transediting (adapting to the requirements and conventions of the target culture). Since then, transediting has been adopted in a wide range of articles to shed light on the way that mass media works (see Aktan and Nohl 2010; Zhang 2012). To Schäffner $(2012,869)$, the studies adopting transediting have focused on specific language pairs, investigated specific cases, and analyzed the corpus via the term transediting. Moreover, the term has been used in different ways. Chen $(2009,204)$ aptly asserts that transediting, in a sense, means gatekeeping, since it refers to filtering and deciding which piece of news is to be transferred. Along the same lines, Hursti (2001), examining the translation from Reuters News Agency to the Finnish Agency, pointedly refers to transediting and gatekeeping as "two faces of the same coin."

Christina Schäffner (2012), on the other hand, rightly claims that the additions, omissions, and substitutions in translation stem from the nature of the act of translation, thus making the term "transediting" redundant. Moreover, she maintains that from the functionalist perspective in translation studies, since one has to take the function of the target text into consideration, transediting does not offer much value in explaining the role of the journalist. Van Doorslaer (2012), on the other hand, offers the term "journalator" to be used in parallel with transediting, as "an interventionist newsroom worker who makes abundant use of translation while transferring and reformulating or recreating informative journalistic texts." Given the fact that written translation is examined in these papers, this paper offers a different perspective from the point of oral translation, interpreting.

Adapting the term to the interpreting context, since the interpreters/editors hold dual roles in the TV interpreting field in Turkey, it is hypothesized that the term interediting might be coined to depict the role of the interpreters/journalists as well as defining the process of TV interpreting. This paper takes interpreting as verbal translation (performed in the medium of TV) and editing as deciding the policy and contents of a piece of paper in an attempt to make 
transLogos 2019 Vol 2 Issue 1

Arzık Erzurumlu, Özüm, pp. 68-84

it suitable for one's goal. ${ }^{4}$ Combining the two terms, I contend that interediting might be used to denote the corroboration of editing and interpreting, since the full-time interpreters/journalists adopt a journalistic viewpoint in the way they interpret. It therefore follows that the interpreters, in rendering the speech, add, delete, and substitute lexical items in line with the editing guidelines internalized as a consequence of their role. The interpreters/journalists, therefore, manifest an active interventionist attitude in the interpreting output. $^{5}$

Drawing on the interviews conducted with the interpreters and the case studies analyzed, the term interediting will be tested in what follows. In light of the theoretical discussion, the question to what extent and under which circumstances interediting comes into play will be answered.

\section{Methodology}

The study was conducted with an inductive approach, and exploratory qualitative design was used. I used the snowball technique and conducted interviews with the interpreters/journalists in an attempt to get a better grasp on their lexical choices and analyze them appropriately. My general inclusion criteria were that they served as interpreters and were full time-employees in the media outlets analyzed. As for the media outlets, I selected two private and two public news outlets that have had a full-time in-house interpreter for more than a decade. Moreover, I also talked to the editors-in-chief to see the full picture. Only at the private TV channels could I access the editors-in-chief. I contacted the subjects myself and informed them about the research, taking their verbal permission to have their sound recorded. The fact that all the participants are full-time staff means their language levels have already been screened. It must be noted, however, that there is a clear difference between English and Kurdish/Arabic interpreters in that the English interpreters/editors go through a screening test before being hired. This screening exam includes three texts to be interpreted by the candidate: one on politics, one on economy, and another text on a social event in all the channels investigated (anonymous respondent, pers. comm.). In the case of Kurdish/Arabic interpreters, however, such a screening exam is not employed.

\footnotetext{
${ }^{4}$ The New Webster's Dictionary of the English Language (New York: Lexicon International, 1995), s.vv. "interpreting," "editing."

${ }^{5}$ For more information on interediting, see Arzık Erzurumlu (2016).
} 
transLogos 2019 Vol 2 Issue 1

Arzık Erzurumlu, Özüm, pp. 68-84

trans Dogos

A Translation Studies Journal

Interediting: Revealing the Dual Role of Staff

Interpreters on Turkish News Channels

(C) Diye Global Communications diye.com.tr|diye@diye.com.tr

All participants were interviewed in Turkish. A semi-structured interview style was employed, and an interview guide was prepared in advance. The questions were open-ended and aimed at understanding the respondents' takes on interpreting, their role, and strategies. I divided the interview into three parts: informative, factual, and conceptual levels. Interviews were conducted face to face, whereas the interview with the Kurdish interpreter was conducted online due to his time constraints. The interviews lasted approximately one hour, were digitally recorded, and manually transcribed. A total number of 11 interviews were conducted between December 2014 and December 2015. I made the data anonymous. As for the interpreting instances, I took the data from the archives of the private TV channels and used the instances to shed light on the findings of the interviews. With the aim of focusing specifically on the 'gatekeeping' aspect of interediting, the instances that include politically controversial utterances were selected for analysis in the present study. I conducted in-depth interviews with the interpreters of these interpreting cases. In the case of the $\mathrm{NC1}$ correspondent and NC2 Cameraman, since they serve as interpreters in Kurdish-Turkish and Arabic-Turkish pairs when the need arises, I included them in the dataset.

Table 1. Demographics of the interviewees.

\begin{tabular}{|c|c|c|c|c|c|}
\hline $\begin{array}{l}\text { INTERPRETE } \\
\mathrm{R}\end{array}$ & $\begin{array}{l}\text { GENDE } \\
\mathrm{R}\end{array}$ & $\begin{array}{l}\text { LEVEL OF } \\
\text { EDUCATION }\end{array}$ & $\begin{array}{l}\text { INTERPRETE } \\
\text { R TRAINING }\end{array}$ & $\begin{array}{l}\text { YEARS OF } \\
\text { JOURNALISM } \\
\text { EXPERIENCE }\end{array}$ & $\begin{array}{l}\text { LANGUAGES } \\
\text { INTERPRETE } \\
\text { D }\end{array}$ \\
\hline $\mathrm{NC} 1 \mathrm{INT}^{\mathrm{d}} 1$ & $\mathrm{~F}$ & B.A GRADUATE & YES & 1.5 & ENG-TR \\
\hline NC1 INT 2 & $\mathrm{~F}$ & B.A GRADUATE & YES & 8 & ENG-TR \\
\hline NC2 INT & $\mathrm{F}$ & B.A GRADUATE & YES & 7 & ENG-TR \\
\hline NC3 INT 1 & $\mathrm{~F}$ & B.A GRADUATE & YES & 16 & ENG-TR \\
\hline NC3 INT 2 & $\mathrm{~F}$ & B.A GRADUATE & YES & 16 & ENG-TR \\
\hline NC4 INT 1 & $\mathrm{~F}$ & B.A GRADUATE & $\mathrm{NO}$ & 5 & ARABIC-TR \\
\hline NC4 INT 2 & $\mathrm{M}$ & B.A GRADUATE & $\mathrm{NO}$ & 7 & ARABIC-TR \\
\hline NC1 C.ED ${ }^{a}$ & $\mathrm{M}$ & POSTGRADUATE & $\mathrm{NO}$ & 16 & \\
\hline NC2 C.ED & $\mathrm{M}$ & B.A GRADUATE & $\mathrm{NO}$ & 28 & \\
\hline $\mathrm{NC} 1 \mathrm{COR}^{\mathrm{b}}$ & $\mathrm{M}$ & B.A GRADUATE & $\mathrm{NO}$ & 11 & ARABIC-TR \\
\hline $\mathrm{NC} 2 \mathrm{CAM}^{\mathrm{c}}$ & M & $\begin{array}{l}\text { HIGH SCHOOL } \\
\text { GRADUATE }\end{array}$ & NO & 24 & KURDISH-TR \\
\hline
\end{tabular}

${ }^{\mathrm{a}} \mathrm{c}$. ed: editors-in-chief

bcor: correspondent

cam: cameraman

dint: interpreter 
transLogos 2019 Vol 2 Issue 1

Arzık Erzurumlu, Özüm, pp. 68-84

\section{Test Cases: Interview Findings and Interpreting Instances}

\subsection{The Interviews}

The present section will offer interview excerpts from the interviews made with the respondents. It appears that in describing the interpreting process, they inevitably refer to their role as editors, claiming that they learn about the news language in editing.

\section{Quote from NC1 Interpreter 2}

All the in-house interpreters edit news in the news outlets, thereby learning the language of the news. I learn the terminology while editing the news. Nobody guided me. Based on my own observations, I started using the terminology of the news. In this regard, I might say that it is a process of self-education. ${ }^{6}$

Not only are the interpreting and editing roles intertwined, but it also appears that the editing role impinges on the lexical choices. The example below manifests a case in point.

\section{Quote from NC1 Interpreter 1}

Working as an editor introduces me to certain terminology. To cite an example, we say Northern Iraq when the speaker says the Kurdish Regional Administration. It is not something forced upon me. That's the first term to come to my mind in the process of interpreting it.

With regard to the strategies employed by the interpreters/journalists, omission is one of the strategies they resort to as an extension of the 'editorial reflex,' as most of the respondents call it.

\section{Quote from NC1 Correspondent/Interpreter 2}

I was interpreting a session of the Syrian parliament for the TV audience. The Syrian parliament called out some names and I asked myself whether I should stop interpreting, since the audience would not know who they are. Then I stopped interpreting, a decision made in the context of my journalistic discretion. As the editors saw that the interpreting had stopped, they stopped broadcasting this session.

As the excerpt manifests, the editorial stance comes to the fore rather than the norm of interpreting the entire text in conference interpreting. The presence of the audience watching and/or listening to the interpreting not only bears upon the lexical choice but also the act of omission as the interpreters/journalists take the audience and their understanding of the text as a yardstick.

\footnotetext{
${ }^{6}$ All translations are mine unless otherwise stated.
} 
transLogos 2019 Vol 2 Issue 1

Arzık Erzurumlu, Özüm, pp. 68-84

trans Dogos

A Translation Studies Journal

Interediting: Revealing the Dual Role of Staff

Interpreters on Turkish News Channels

(C) Diye Global Communications diye.com.tr|diye@diye.com.tr

Having offered the close connection between editing and interpreting and the impact of editing on the process of interpreting, it might make sense to look into the matter more closely and see the impact of interediting on the subjects. As one of the respondents reports, he/she edits and interprets simultaneously so that the layman will understand, the rendering will be neutral, and the top management will not frown upon it, meaning the institutional policies will be followed. For him/her, the lexical substitutions that are required to be made are confusing.

\section{Quote from NC2 Interpreter}

I am in a dilemma. There might be three different versions of interpreting. The first is the one that a layman would understand. The second is what the speaker says and the third is the one that the executives would like. So, I make a mixed version of these. What I do is I interpret what the speaker says in a way that could be understood by the people on the street. Yet, this is difficult, exhausting.

As the above sentences illustrate, the interpreter/journalist explicitly mentions the potential lexical transformations that the speech might go through in the course of interpretation. To $\mathrm{him} / \mathrm{her}$, the lexical substitutions draw their legitimacy from his/her role as an editor.

To another interpreter, serving as an interpreter and editor eases her job as an interpreter.

\section{Quote from NC2 Interpreter}

Working for an institution has an advantage with regard to the ease of preparation. That is, I mostly interpret on the subject matters that I know about. The preparation phase, therefore, is much shorter than that required of the freelance interpreters. When the interpreter knows the dates, concepts, and figures that the speaker talks about, then his/her job gets easier.

It appears that with regard to the perception of the interpreters of their own role, 'newsperson' emerges as the term mentioned most. Merriam-Webster defines 'newsperson' as a person reporting, gathering, and commenting on the news. Yet, becoming a newsperson does not happen overnight. NC1 Interpreter 2 contends that it takes six to seven years to improve yourself as a journalist, and only in time you begin to see the events from a journalist's point of view.

\section{Quote from NC1 Correspondent 2}

If a person is trained only as an interpreter, then he/she might interpret literally. However, as I am a newsperson and a world news desk editor as well as simultaneous interpreter, journalistic reflexes play out. I might skip terms depending on these reflexes. 
transLogos 2019 Vol 2 Issue 1

Arzık Erzurumlu, Özüm, pp. 68-84

As regards the sources of their role as editors, state policy comes to the fore, especially in the case of publicly owned TV channels.

An interpreter working for a public channel maintains that the senior management directly informs them about the prohibited terms, when such terms occur as an extension of the state policy. This case holds true for the other state-owned TV channel.

\section{Quote from NC3 Interpreter 1}

The announcement as to which terms we should apply is hung up on a board. The terms we need to employ are dictated to us by the senior management. We need to have a joint news language.

When it comes to sanctions the interpreter might incur should he/she not abide by his/her institution's policies, one respondent commented:

\section{Quote from NC1 Interpreter 1}

Foreign politics and journalism need to be aligned. You need to follow the state policy in journalism; if you do not, the eyebrows of the government will go up.

To one of the interpreters interviewed, the sanctions might even lead to one's losing his/her job.

\section{Quote from NC2 Interpreter}

If you do not preserve the institution, you are more likely to pay the price. It seems, therefore, that you do preserve the institution so as to preserve yourself. If you do not behave that way, then you might fall into disgrace.

As the above excerpts manifest, terms in line with the discourse of the state/government might be enforced across these channels. Since in-house interpreters/journalists need to follow these instructions, lexical substitution, addition or omission might become indispensable.

For the sake of drawing a full picture of TV interpreting in Turkey, it could make sense to consider the case from the point of view of the editors-in-chief. Contrary to the ethical standards in conference interpreting which stipulate the strict 'don't modify the meaning' policy, it seems as if the editors-in-chief are highly satisfied with the impact of editing on rendering.

\section{Quote from NC2 Editor-in-chief}

When you work as an editor, you develop a grasp on the terminology. To cite, while editing news on the EU negotiations, you grow used to the terminology. And when 
transLogos 2019 Vol 2 Issue 1

Arzık Erzurumlu, Özüm, pp. 68-84

trans Dogos

A Translation Studies Journal

Interediting: Revealing the Dual Role of Staff

Interpreters on Turkish News Channels

(C) Diye Global Communications diye.com.tr|diye@diye.com.tr

you interpret, these terms naturally are the first ones that come out of your mouth. It goes without saying that journalism, therefore, definitely contributes to interpreting.

When asked about further details, he mentions editorial values. He counts the values that should be abided by both interpreters and journalists as journalism values and claims that the interpreter should behave as a journalist and think of the implications of the interpreting.

The interviews reveal that the role the interpreters/journalists assume as editors has a bearing on the interpreting output in the sense that the output might go through translation shifts or lexical alterations via addition, omission, and substitution. In what follows, the traces of such shifts will be sought in light of the interpreting instances acquired from the TV channels analyzed.

\subsection{Interpreting Instances}

More than forty interpreting instances have been analyzed in an attempt to illustrate the findings of the interviews. I visited the archives personally, asked for permission, and got the broadcasted interviews on a hard disk. With a view to understanding the reasons behind the lexical choices made, I asked the respondents questions related to these examples. Adopting such a dual perspective enabled me to analyze renderings and corroborate them with the interview findings.

The instances I analyzed were all interpreted by staff interpreters/journalists (professionals and non-professionals) in simultaneous and consecutive mode (only one item was rendered consecutively). Moreover, all the interpreters worked into their mother tongue. As for the types of interaction, they were press meetings, interviews with citizens, and media interviews.

5.2.1 Case 1. Kurdish people fleeing Syria are interpreted from Kurdish into Turkish for a news package "Suruc Tension,"7 lasting 4:35 minutes. The interpreting mode is consecutive. The interpreter, a non-professional, is a cameraman working for the channel. Since he is the only one within the channel speaking sufficient Kurdish to render the speech, he assumes the job of interpreting and adopts lexical substitution. I must note that since I am not competent in Kurdish, a professional interpreter helped me with the translation of the text.

\footnotetext{
${ }^{7}$ The archives of the news channels visited do not seem to keep proper archives in the sense that not all the videos are named, and the producers of these videos are also anonymous. Therefore, no proper reference can be given.
} 
transLogos 2019 Vol 2 Issue 1

Arzık Erzurumlu, Özüm, pp. 68-84

\section{$\underline{\text { Kurdish Source Text }}$}

Îro roja me ye çara ye. Em mirin hemû xwediya me çû. Em çar roje li çolê ne. Em tî û birçî man.

\section{$\underline{\text { Target Text }}$}

Biz 4 gündür çöldeyiz. Yaklaşık bütün malımız mülkümüz orada kaldı. Aç ve susuzuz biz şu anda. Allah Türk devletinden razı olsun diyorlar.

\section{Target Text in English}

We have been in the desert for four days. All our goods are left behind. We are hungry and thirsty. May God bless the Turkish state, they say.

\section{Back Translation in English}

It is our fourth day. We perished. We lost our property. We have been in the desert for four days. We are hungry and thirsty.

The case study displays a high degree of substitution, since the woman who is interviewed never thanks the Turkish state in the source text. As to why the rendition was made this way, the interpreter/journalist says that he basically interpreted what he saw, not the words, as an extension of his role as a journalist. He explains his decision as an extension of the journalist reflex. As far as he is concerned, he interpreted what he saw in the field rather than the words of the speaker: "Since the previous interviewees all thanked the Turkish state, I rendered it the same."

5.2.2 Case 2. In NC2 the senior Middle East correspondent of the daily Independent, Robert Fisk, is connected over the telephone, and his views, interpreted from English into Turkish, are aired live.

\section{Source Text}

It reminds them of the Armenian genocide of 1915.

\section{Target Text}

Çünkü 1915'deki sözde Ermeni soykırımını hatırlattılar.

\section{Back Translation}

Because it reminded of them the so-called Armenian genocide of 1915.

Though this rendition may be described as lexical substitution, the interpreter describes his/her strategy as toning town. Moreover, the interpreter maintains that resorting to toning down as a strategy has to do with the fact that he/she has to abide by the institutional and/or political power at play. 
transLogos 2019 Vol 2 Issue 1

Arzık Erzurumlu, Özüm, pp. 68-84

\subsubsection{Case 3. In an interpreting case in NC1, Armenian singers Omni Dinkjiyan and Ara}

Dinkjiyan were invited to the studio, since it was the Armenian genocide remembrance day.

The program aired on April 21, 2015 and was interpreted live.

\section{$\underline{\text { Source Text }}$}

What do you want to say about the timing of the concert? How do you feel about the timing? It is the 100th anniversary.

\section{$\underline{\text { Target Text }}$}

Peki bu konserin zamanlamasıyla ilgili neler söylemek istersiniz? Zamanlama ile ilgili neler düşünüyorsunuz 100. Yıldönümü çünkü 1915 olaylarının ve Türkiye'desiniz.

\section{Back Translation}

Well, what would you like to say about the timing of the concert? Since it is the 100th anniversary of the events of 1915 and you are in Turkey, what is your take on timing?

As regards the reason behind this expansion or addition, the interpreter explains it as a natural consequence of being imbued with the language of the institution, since he/she serves as an editor on the world news desk. The interpreter adds that "he/she does it naturally, not on purpose." It is not a substitution or addition to him/her, it is only matching the terms. As for why she chose 'the events of 1915 ' over 'the Armenian genocide,' she claims that if she ever said 'the Armenian genocide,' the reaction of the audience would be overwhelmingly negative, and they would bash her, since Turkish authorities strongly deny the Armenian genocide.

As the interpreting instances in which the interpreter resorts to lexical substitution, addition, and toning down manifest, interediting might lead to some lexical alterations in the text. Furthermore, the interpreter/journalist might make themselves visible as journalists and get away from one of the most significant production norms of interpreting, adopting the persona of first-person singular in rendering. In fact, the interpreting instances demonstrate that the staff interpreters seem to be commenting on the interpretation rather than keeping a neutral tone.

\section{Discussion}

In this study, the interediting role assumed by the interpreters/journalists on Turkish TV channels has been explored. The test cases and the qualitative analysis of the interpreting instances and interviews indicate that interpreting is inextricably intertwined with editing on 
transLogos 2019 Vol 2 Issue 1

Arzık Erzurumlu, Özüm, pp. 68-84

trans Dogos

A Translation Studies Journal

Interediting: Revealing the Dual Role of Staff

Interpreters on Turkish News Channels

(C) Diye Global Communications diye.com.tr|diye@diye.com.tr

news channels when it is perpetuated by staff interpreters/journalists. The materials examined in this paper indicate that the modifications in interpreting are informed by the language of the news with which they are imbued during the course of editing the news. The key findings include the determination that the interpreters use strategies that clearly go beyond the task of interpreting. Drawing on the cases analyzed and the interviews conducted, it might be hypothesized that the journalistic role assumed by the respondents has highly impacted their rendition as interpreters. Whereas the professional conference interpreters need to render within professional guidelines, such as those offered by AIIC or the Turkish equivalent of AIIC, the Turkish Conference Interpreters' Association, there are no such binding considerations in place for media interpreters. As the interpreters in our data have expressed, in light of the lack of such regulations, the journalistic role assumed by these interpreter journalists emerges. In the rendition, thus, there might be additions, omissions, or substitutions following the editing guidelines as they have been internalized by the interpreters/journalists. It therefore stands to reason that editing and interpreting are inextricably intertwined as far as interpreters/journalists are concerned.

Colucci $(2011,76)$ pointedly claims that all the interpreter-mediated interactions require a filtering process carried out by interpreters, leading to modifications in the target text. It is my contention that it is incumbent upon researchers to find out the mechanisms behind the filtering process, and I hope the current paper serves to uncover the interpreter/journalist's role in the interediting process. The paper, revealing the way interpreting has been perpetuated on TV channels in Turkey, might contribute to a better understanding of the interaction between the two titles assumed by staff interpreters. It might also be a step towards shedding light on broadcasting officials' responsibilities. Officials should be aware of the negative consequences that might arise by hiring interpreters/journalists. The limitation of the study is the small number of participants, yet the fact that an unprofessional interpreter renders in Kurdish-Turkish exposes one part of the reality of TV interpreting in Turkey, as well as revealing the language policy of Turkish media. More studies are needed to examine the institutional discourse in TV interpreting. 


\section{References}

Aktan, Oktay, and Arnd-Michael Nohl. 2010. "International Trans-Editing: Typical Intercultural Communication Strategies at the BBC World Service Turkish Radio." Journal of Intercultural Communication 24. Accessed March 10, 2019. http://www.immi.se/intercultural/nr24/nohl.htm.

Arzık Erzurumlu, Özüm. 2016. “Gatekeepers as a Shaping Force in TV Interpreting.” PhD diss., Doğuş University.

. 2019. “Trump'ça: Türkçede Trump'1 Yeniden Yazmak.” In Türkiye'de Sözlü Çeviri: Eğitim, Uygulama ve Araştırmalar 1 [Simultaneous interpreting in Turkey: Education, application and research 1], edited by Ebru Diriker, 153-191. Istanbul: Skala.

Buck, Vincent, and Chikako Tsuruta. 2012. "Exploring media interpreting." aiic.net. March 13. Accessed June 30, 2019. http://aiic.net/p/3851.

Chen, Ya-mei. 2009. "Quotation as a Key to the Investigation of Ideological Manipulation in News Trans-Editing in the Taiwanese Press." TTR 2 (2): 203-238. doi: 10.7202/044830ar.

Colucci, Chiara. 2011. "Modalisation and Pragmatics in Simultaneous TV Interpreting. A Case Study: American Presidential Debates.” The Interpreters' Newsletter 16: 61-80.

Dal Fovo, Eugenia. 2013. "Simultaneous Interpretation on Television: The Case of the Question/Answer Group in the 2004 U.S. Presidential Debathon." PhD diss., University of Trieste.

2015. "Media Interpreting." In Routledge Encyclopedia of Interpreting Studies, edited by Franz Pöchhacker, 245-247. London: Routledge.

Doorslaer, Luc van. 2012. "Translating, Narrating and Constructing Images in Journalism with a Test Case on Representation in Flemish TV News." Meta 57 (4): 1046-1059. doi:10.7202/1021232ar.

Falbo, Caterina. 2012. "CorIT (Italian Television Interpreting Corpus): Classification Criteria." In Breaking Ground in Corpus-based Interpreting Studies, edited by Straniero Sergio and Caterina Falbo, 155-185. Bern: Peter Lang.

Hursti, Kristian. 2000. "On the Relationship of the Translatorial and Organisational Aspects of International News Communication from English into Finnish: An Insider's View." Master's thesis, University of Helsinki.

2001. "An Insider's View on Transformation and Transfer in International News Communication: An English-Finnish Perspective." The Electronic Journal of the Department of English at the University of Helsinki 1. https://blogs.helsinki.fi/heseng/volumes/volume-1-special-issue-on-translation-studies/an-insiders-view-on- 
transformation-and-transfer-in-international-news-communication-an-english-finnishperspective-kristian-hursti/.

Kurz, Ingrid. 1990. “Overcoming Language Barriers in European Television.” In Interpreting Yesterday, Today and Tomorrow, edited by David Bowen and Margareta Bowen, 168175. Binghamton: State University of New York.

1993. "The 1992 U.S. Presidential Elections: Interpreting the American Debathon for Austrian Television." In Translation: The Vital Link; Proceedings of the 13th FIT World Congress, edited by Catriona Picken, 1: 441-445. London: Institute of Translation and Interpreting.

. 1997. "Getting the Message Across: Simultaneous Interpreting for the Media." In Translation as Intercultural Communication, edited by Maria Snell-Hornby, Zuzana Jettmarová, and Klaus Kaindl, 195-205. Amsterdam: John Benjamins.

—. 2002. "Physiological Stress Responses during Media and Conference Interpreting." In Interpreting in the 21st Century: Challenges and Opportunities, edited by Giuliana Garzone and Maurizio Viezzi, 195-202. Amsterdam: John Benjamins.

Munday, Jeremy. 2017. “A Modal of Appraisal: Spanish Interpretations of President Trump's Inaugural Address 2017.” Perspectives: Studies in Translatology 26 (2): 180-195. doi: 10.1080/0907676X.2017.1388415.

Pöchhacker, Franz. 2007. "Coping with Culture in Media Interpreting." Perspectives: Studies in Translatology 15 (2): 123-142. doi:10.1080/13670050802153798.

- 2010. "Media Interpreting." In Handbook of Translation Studies, Yves Gambier and Luc van Doorslaer, 1: 224-226. Amsterdam: John Benjamins.

- 2011a. "Conference interpreting." In The Oxford Handbook of Translation Studies, edited by Malmkjær Kirsten and Kevin Windle, 307-324. Oxford: Oxford University Press.

—. 2011b. "Researching TV Interpreting: Selected Studies of US Presidential Material." The Interpreters' Newsletter 16: 21-36.

Schäffner, Christiana. 2008. “The Prime Minister said. . .': Voices in Translated Political Texts." SYNAPS 22: 3-25.

- 2012. "Rethinking Transediting." $\quad$ Meta $57 \quad$ (4): 866-883. doi: $10.7202 / 1021222$ aradresse.

Snelling, David C. 1997. "On Media and Court Interpreting." In Conference Interpreting: Current Trends in Research; Proceedings of the International Conference on Interpreting; What Do We Know and How?, edited by Yves Gambier, Daniel Gile, and Christopher Taylor, 187-206. Amsterdam: John Benjamins. 
transLogos 2019 Vol 2 Issue 1

Arzık Erzurumlu, Özüm, pp. 68-84

trans Dogos

Interediting: Revealing the Dual Role of Staff

Interpreters on Turkish News Channels

(C) Diye Global Communications diye.com.tr | diye@diye.com.tr

Stetting, Karen. 1989. "Transediting: A New Term for Coping with a Gray Area between Editing and Translating." Proceedings of the Fourth Nordic Conference for English Studies, edited by Graham Cate, Kirsten Haastrup, and Arnt L. Jakobsen, 371-382. Copenhagen: University of Copenhagen.

Tsuruta, Chikako. 2011. "Broadcast Interpreters in Japan: Bringing News to and from the World.” The Interpreters' Newsletter 16: 157-173.

Viaggio, Sergio. 2001. "Simultaneous Interpreting for Television and Other Media: Translation Doubly Constrained." In (Multi)Media Translation: Concepts, Practices and Research, edited by Yves Gambier and Henrik Gottlieb, 23-33. Amsterdam: John Benjamins.

- 2006. A General Theory of Intercultural Mediation. Berlin: Frank and Timme Verlag.

Zhang, Meifang. 2012. "Stance and Mediation in Transediting News Headlines as Paratexts." Perspectives: $\quad$ Studies in Translatology 20 (1): 1-16. doi: 10.1080/0907676X.2012.691101. 